\title{
Detection of Bacterial Contamination in Imported Live Poultry Vaccines to Egypt in 2018
}

\author{
Mohamed Morsi Elkamshishi ${ }^{1 *}$, Haitham H. Ibrahim² and Hanan M. Ibrahim ${ }^{3}$ \\ ${ }^{I}$ Department of Animal Hygiene and Zoonoses, Faculty of Veterinary Medicine, Matrouh University, Egypt \\ ${ }^{2}$ Department of Avian and Rabbit Medicine, Faculty of Veterinary Medicine, Aswan University, Egypt \\ ${ }^{3}$ Head of researcher Central Laboratory for Evaluation of Veterinary Biologics (CLEVB) El-Seka El-Baida, Abbasia, Cairo, Egypt \\ "Corresponding author's Email: elkamshishymohamed@yahoo.com; ORCID: 0000-0002-2145-0663
}

Received: 19 Feb. 2020

Accepted: 29 Mar. 2020

\begin{abstract}
The vaccine is one of the most important biological products used in the poultry industry, thus it must be safe, potent, and effective. This work presents the results of a large-scale diagnostic survey performed in Egypt to study hygienic epidemiology and how vaccination may affect the viral circulation in the field. This study aimed to detect bacterial contamination in live poultry vaccines imported to Egypt during 2018. In this study, 285 consignments poultry vaccines, including 114 consignments live vaccine, 103 consignments recombinant vaccines, and 68 consignments killed vaccines (imported through Cairo airport during 2018) were examined for bacterial contamination. The vaccines were imported from USA, Italy, France, Spain, Mexico, and China. Bacterial contamination with Salmonella species was detected using the VITEK 2 system in two samples $(1.8 \%)$ (IB+HB1 vaccine imported from Italy and ILT vaccine imported from USA).
\end{abstract}

Key words: Bacterial contamination, Egypt, Poultry, Vaccine

\section{INTRODUCTION}

Egypt has a large sector of poultry, more than 50 thousand commercial producers and poultry farming systems (Ali et al., 2013).

Egyptian requirements for imported animals and poultry by-products are governed by the epidemiological situation of the country and by the law of Agriculture No. 53, 1966, and Ministerial Decree No. 47, 1967 concerning veterinary quarantine, and its modifications.

Vaccines are widely used in the prevention and reduction of incidence as well as control of endemic poultry and animal diseases. For a vaccine to be useful in the maintenance of animal and poultry health, it must be pure, safe, potent, and effective (OIE, 2014).

In Egypt, the Central Laboratory for Evaluation of Veterinary Biologics (CLEVB) is the authorized governmental laboratory for the evaluation and certification of veterinary vaccines and biological products prior to their release into the markets (Ministerial Decree No. 2978/2003). Despite essential to proper control of the disease, the massive use of live vaccines has some drawbacks. The impact of vaccination protocols on circulating strains proved remarkable and some lineages even disappeared after the discontinuance of homologous vaccination (Franzo et al., 2014 and 2016). Live vaccine strains may spread to unvaccinated flocks, regain virulence because recombine with other circulating strains, possibly resulting in the emergence of new strains (Matthijs et al., 2008; Jackwood and Lee, 2017; Moreno et al., 2017).

Hence, the aim of this work was to detect bacterial contamination in live poultry vaccines imported to Egypt during 2018.

\section{MATERIAL AND METHODS}

\section{Vaccine samples}

As shown in Table 1, about 114 consignments of live poultry vaccines entered Egypt during 2018 each consignment represented by 5 vials.

Table 1. Types and numbers of imported poultry vaccines to Egypt

\begin{tabular}{lcc}
\hline Killed vaccines & $\begin{array}{c}\text { Recombinant } \\
\text { vaccines }\end{array}$ & Live vaccines \\
\hline 68 consignments & 103 consignments & 114 consignments \\
\hline
\end{tabular}




\section{The media used for detection of bacterial contamination \\ Broth media}

Tryptose broth (Non-selective enrichment) produced by Oxoid Company, batch No.147644/318 prepared and sterilized according to the manufacturer's instruction.

\section{Selective isolated media}

Two selective isolated medium (MacConkey of batch No.2301758 code CMO115, produced by Oxoid company, and Salmonella-Shigella agar of batch NO.2235930 produced by Oxoid company are prepared and sterilized according to the manufacturer's instruction. Xylose Lysine Deoxycholate Agar (XLD): Batch No.2283742 produced by Oxoid Company, prepared and sterilized according to the manufacturer's instruction.

\section{Procedure}

The procedures are applied according to OIE (2016)

1. Sample preparation:

- If the vaccine sample contains 1000 doses or more so the vaccine was rehydrated at a rate of $30 \mathrm{ml}$ sterile distal water/1000 dose.

- In case the vaccine sample in liquid phase the test portion will be $5 \mathrm{ml}$ or one-half of the container contents, whichever is the lesser.

2. Inoculation and incubation:

- Tryptose broth (Non-selective enrichment) 100 $\mathrm{ml}$ is inoculated with $5 \mathrm{ml}$ of the rehydrated sample or 50 $\mathrm{ml}$ or one-half of the container contents, whichever is the lesser.

- The inoculated broths are incubated for 18-24 hours at $35-37^{0} \mathrm{C}$.

- Two selective isolated medium (MacConkey and Salmonella-Shigella agar) are inoculated from the nonselective broth (Tryptose broth) then incubated for 1824 hours at $35-37^{\circ} \mathrm{C}$ and examined.

- If on growth of typical Salmonella is noticed, the agar plates should be incubated an additional 18-24 hours at $35-37^{\circ} \mathrm{C}$ and re-examined.

- If colonies typical of Salmonella are observed, further subculture on to the Xylose Lysine Deoxycholate agar (XLD) is incubated at $35-37^{0} \mathrm{C}$.

3. Interpretation:

- Interpretation depends on the presence or absence of the typical colony of Salmonella.

- No growth (Not detected) means satisfactory results and Salmonella growth (detected) means unsatisfactory results.

4. The identification:

The bacterial contamination was identified as Salmonella species using the VITEK 2 system.

\section{RESULTS}

During 2018 Egypt imported 285 consignments poultry vaccines, including 114 consignments, live vaccine, 103 consignments recombinant vaccines, and 68 consignments killed vaccines through Cairo airport. As shown in table 2, the vaccines imported from different countries as USA, Italy, France, Spain, Mexico, and China. All imported live vaccines were examined for bacterial contamination, two samples one is $\mathrm{IB}+\mathrm{HB} 1$ vaccine imported from Italy and the other was ILT vaccine imported from USA are detected bacterial contamination (by ratio $1.8 \%$ ), these contaminated bacteria were identified as Salmonella species using VITEK 2 system.

Table 2. The import companies of poultry vaccines in Egypt

\begin{tabular}{lc}
\hline Import company & Country of origin \\
\hline M.Ghannam & USA, Italy, France, Spain, Mexico \\
Intervet & USA \\
Axis Agency Services LTD.co. & USA \\
Zoetis Egypt & USA \\
Biopharma trading & China \\
International free trading & USA, Italy, France, Mexico \\
\hline
\end{tabular}

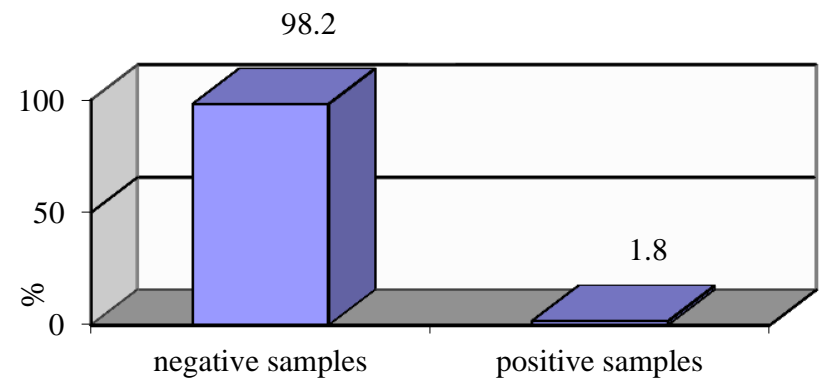

Figure 1. Prevalence of bacterial contamination in imported live poultry vaccines to Egypt during 2018

\section{DISCUSSION}

Vaccine is still the most important tool for the control and prevention of poultry diseases. Their use in the poultry industry avoids or minimizes the clinical disease in the farms and increase production. Sterility testing is a process that confirms the presence or absence of any viable contaminating microorganisms in biological products (Lee, 1990). 
In this study, all live poultry viral vaccines enter Egypt during 2018 were examined for bacterial contamination, only two consignments out of $114(1.8 \%)$ were refused due to contamination with Salmonella. Most researchers have carried out their investigation on the vaccine samples for the detection of viral contamination either by complete virus, antigens, or nucleic acids (Kamboh et al., 2009c). Kamboh et al. (2009a) recorded the $7.5 \%$ bacterial contamination in livestock vaccines and Kamboh et al. (2007) isolated $10.71 \%$ extraneous contaminants in local livestock vaccines used in Sindh province of Pakistan.

The results obtained in the present study are in agreement with that obtained by Kamboh et al. (2009b) who found that lower bacterial contamination $(2.08 \%)$ in poultry vaccines.

In this study, the isolated bacterial contaminants were identified as Salmonella species using VITEK 2 system which is a rapid system for identification of the gram-negative rods (including both members of the family Enterobacteriaceae and non-enteric bacilli) this system has been evaluated for identification of gram-negative bacilli by Guido et al. (1998). Samad (2001) reported the contamination of Bacillus megaterium, B. cereus, B. mycoids and $B$. subtilis in the local anthrax livespore vaccines. Whereas, Kojima et al. (1997) reported the contamination of avian Mycoplasma DNA in the avian live virus vaccines. Kamboh et al. (2009b) found $E$. coli in the vaccine of hydropericardium syndrome. Landman et al. (2000) found contamination of Marek's disease vaccine by Enterococcus faecalis.

\section{DECLARATIONS}

\section{Competing interests} interests.

The authors declare that they have no competing

\section{Authors' contributions}

Mohamed Morsi Elkamshishi laboratory design and publishing, Haitham.H.Ibrahim collected the data and wrote the manuscript, Hanan M. Ibrahim performed the laboratory work and analysis of the results.

\section{REFERENCES}

Ali A, Ankers P, DeHaan N, Saad A, Hussein S, Lubroth J and Jobre Y (2013). Mapping influenza A (H5N1) virus transmission pathways and critical control points in Egypt. FAO Animal Production and Health Working. Available at: http://www.fao.org/docrep/017/i3272e/i3272e.pdf

Franzo G, Naylor CJ, Lupini C, Drigo M, Catelli E, Listorti V, Pesente P, Giovanardi D, Morandini E and Cecchinato M (2014). Continued use of IBV 793B vaccine needs reassessment after its withdrawal led to the genotype's disappearance. Vaccine, 32:6765-6767. DOI: 10.1637/11557-121216-ResNote.1

Franzo G, Tucciarone CM, Blanco A, Nofrarías M, Biarnés M, Cortey M, Majó N, Catelli E and Cecchinato M (2016). Effect of different vaccination strategies on IBV QX population dynamics and clinical outbreaks. Vaccine, 34:5670-5676.DOI: 10.1016/j.vaccine.2016.09.014

Funke G, Monnet D, de Bernardis C, von Graevenitz A and Freney J (1998). Evaluation of the VITEK 2 system for rapid identification of medically relevant gram-negative rods. Journal of Clinical Microbiology, 36(7):1948-1952. DOI: 10.1128/JCM.36.7.19481952.1998

Jackwood MW and Lee DH (2017). Different evolutionary trajectories of vaccine-controlled and non-controlled avian infectious bronchitis viruses in commercial poultry. PLoS One, 12(5):e0176709. DOI: 10.1371/journal.pone.0176709

Kojima A, Takahashi T, Kijima M, Ogikubo Y, Nishimura M, Nishimura S, Harasawa R and Tamura Y (1997). Detection of Mycoplasma in avian live virus vaccines by polymerase chain reaction. Biologicals, 25: 365-371. DOI: 10.1006/biol.1997.0108

Kamboh AA, Rind R, Shah AH, Gandahi JA and Rajput N (2007). Bacteriological study on local and imported livestock vaccines used in Sindh, Pakistan Journal of Agricultural Sciences, 3: 125-128. http://www.fspublishers.org

Kamboh AA, Rajput N, Rajput IR, Khaskheli M and Khaskheli GB (2009a). Biochemical properties of bacterial contaminants isolated from livestock vaccines. Pakistan Journal of Nutrition, 8: 578-58. DOI: $10.3923 /$ pjn.2009.578.581

Kamboh AA, Gandahi JA, Shah AH, Zhu WY, Malhi M, Rind R, and Babar ME (2009c). An evaluation for bacterial contamination of vaccines for buffaloes used in Pakistan. Pakistan Journal of Zoology, 9: 639-643. https://www.researchgate.net/publication/209836381.

Kamboh AA, Arain ZM, Rajput N and Abro SH (2009b). A study on bacterial contamination of poultry vaccines. Journal of Agriculture and Social Science, 5: 46-48. https://www.cabdirect.org/cabdirect/abstract/20093150323.

Lee JY ( 1990). Investigating Sterility Test Failure. Pharm. Technol., 3843.

Landman WJM, Veldman KT, Mevius DJ and Doornenbal P (2000). Contamination of Marek's disease vaccine suspensions with Enterococcus faecalis and its possible role in amyloid arthropathy. Avian Pathology, 29: 21-25.DOI: 10.1080/03079450094234

Matthijs MGR, Bouma A, Velkers FC, van Eck JHH and Stegeman JA (2008). Transmissibility of infectious bronchitis virus H120 vaccine strain among broilers under experimental conditions. Avian Disease. 52:461-466. DOI: 10.1637/8204-010708-Reg.1

Moreno A, Franzo G, Massi P, Tosi G, Blanco A, Antilles N, Biarnes M, Majó N, Nofrarías M, Dolz R et al. (2017). A novel variant of the infectious bronchitis virus resulting from recombination events in Italy and Spain. Avian Pathology, 46:28-35. DOI: 10.1080/03079457.2016.1200011

OIE (2014). Infection disease in OIE quality standard and guidelines for veterinary laboratories (world organization for health).

OIE (2016). Infection disease in OIE quality standard and guidelines for veterinary laboratories (world organization for health).

Samad A (2001). Use of antimicrobial susceptibility pattern as an identification marker of vaccinal and wild type strains of Bacillus anthracis in vaccine manufacturing process. M.Sc. thesis, Department of Veterinary Microbiology, Sindh Agriculture University, Tandojam. 